\title{
Survey of Contents
}

\begin{tabular}{|c|c|c|}
\hline Section & & Page \\
\hline $1-22$ & I. Introduction & 3 \\
\hline $2-4$ & A. Historical Factors & 3 \\
\hline $5-6$ & B. Topical Coverage & 5 \\
\hline $7-9$ & C. Caveat - Book Law v. Practice & 5 \\
\hline $10-19$ & D. Principal Approaches to Legitimacy and Illegitimacy & 7 \\
\hline $20-2 \mathrm{I}$ & E. Adoption & 12 \\
\hline 22 & F. Method of Presentation and Geographic Coverage & 12 \\
\hline $23-60$ & II. Legitimacy & $\mathrm{r}_{4}$ \\
\hline $23-37$ & A. Definition, Presumption and Challenge & I4 \\
\hline $38-44$ & B. Legitimation Through Invalid Marriage & $2 \mathrm{I}$ \\
\hline $45-5 I$ & C. Effect of Informal Marriage & 22 \\
\hline $52-59$ & D. Legitimation Through Marriage After the Child's Birth & 25 \\
\hline 60 & E. Legitimation by Father & 27 \\
\hline $6 \mathrm{I}-\mathrm{IOI}$ & III. Ascertainment of Paternity (and Maternity) & 28 \\
\hline $6 \mathrm{I}-76$ & A. Voluntary Acknowledgment & 28 \\
\hline $77-9 \mathrm{I}$ & B. The Paternity Action & 34 \\
\hline $92-\mathrm{IOI}$ & C. Scientific Evidence of Paternity & 50 \\
\hline $102-147$ & IV. The Illegitimate Child's Substantive Rights & 57 \\
\hline IO3-II4 & A. Support & 57 \\
\hline II $5-127$ & B. Inheritance & 62 \\
\hline I28-139 & C. Custody, Visitation & 66 \\
\hline I $40-147$ & D. The Surname of the Illegitimate Child & 70 \\
\hline $148-196$ & V. Adoption & 73 \\
\hline I $49-155$ & A. The Nature of Adoption & 73 \\
\hline $156-168$ & B. Who May Adopt Whom? & 76 \\
\hline $169-176$ & C. Who Must Consent? & $8 \mathrm{I}$ \\
\hline $177^{-1} 86$ & D. Effect of Adoption & 86 \\
\hline I $87-$ I96 & E. Revocation of Adoption & $9 \mathrm{r}$ \\
\hline I97-199 & VI. Artificial Insemination & 96 \\
\hline & List of Principal Works & 97 \\
\hline & List of Statutory Material & 99 \\
\hline & Detailed Table of Contents & IOI \\
\hline
\end{tabular}

(C) 976 MOUton, the hague, and J. C. B. MOHR (PAUl SiEBECK), TÜBINGEN

THIS CONTRIBUTION HAS BEEN FINANCIALLY SPONSORED BY THE STIFTUNG VOLKSWAGENWERK IN HANNOVER (GERMANY) 